\title{
地球低軌道における軌道環境の安定性について*1
}

\section{Instability of the Current Space Debris Population in Low Earth Orbit}

\author{
眞 庭 知 成 ${ }^{* 2} \cdot$ 花 田 俊 也*3 $\cdot$ 河 本 聡 美*4 \\ Kazuaki Maniwa, Toshiya Hanada and Satomi Kawamoto
}

Key Words : Orbital Debris, Modeling, Space Environment, Simulation

\begin{abstract}
Since the launch of Sputnik, orbital debris population continues to increase due to ongoing space activities, on-orbit explosions, and accidental collisions. In the future, it is expected that a great deal of fragments will be created by explosions and collisions. Thus, the number of space debris may increase exponentially (Kessler Syndrome). This paper analyzes the Kessler Syndrome using the Low Earth Orbital Debris Environmental Evolutionary Model (LEODEEM) developed at Kyushu University with collaboration from JAXA. The purpose of the study aims at understanding the issues related to space environment conservation. The results provide effective conditions of Active Debris Removal which is one of the space debris mitigation procedures.
\end{abstract}

記 号の説明

$\begin{aligned} R & : \text { 摂動関数 } \\ \bar{R} & : \text { 摂動関数の長周期項および永年項 } \\ P & : \text { 軌道周期 } \\ M & : \text { 平均近点離角 } \\ r & : \text { 軌道半径 } \\ U & : \text { 相対速度 } \\ C & : \text { 衝突率 } \\ A & : \text { 衝突断面積 } \\ V & : \text { 衝突球の体積 } \\ \Delta V & : \text { 重複体積 } \\ m & : \text { 物体の質量 }\left(m_{1}>m_{2}\right) \\ p & : \text { 物体が衝突球内に存在する確率 } \\ & \end{aligned}$

$\mathrm{p}, \mathrm{a}$ : 近地点, 遠地点

$\max , \min$ : 最大值，最小值

$1,2:$ 物体 1, 物体 2

\section{1. 緒言}

現在「スペースデブリ」による宇宙環境の悪化は深刻化 してきている .これまではスペースデブリの数が少なかっ たために弚の存在が注目されることはなかったが, ロケッ 卜上段機体の爆発などにより加速的に光の数が増加した . 1990 年代にはスペースシャトルや回収された軌道上物体 にスペースデブリの衝突痕が何度も確認され，光の危険性

\footnotetext{
*1 C 2010 日本航空宇宙学会

平成 21 年 5 月 27 日原稿受付

*2 九州大学大学院工学府航空宇宙工学専攻

*3 九州大学大学院工学研究院航空宇宙工学部門

$* 4$ 宇宙航空研究開発機構研究開発本部
}

が認識され始めた . 最近の例としては , 2007 年と 2008 年 に国際宇宙ステーション (ISS, International Space Station)において , スペースデブリとの衝突痕か碓認されてお り1,2)，また， 2009 年 2 月には運用中の人工衛星と運用が 終了して放置されていた人工衛星か衝突し, 多数のスペー スデブリが発生した .これらのことから，スペースデブリ が宇宙空間において危険な存在であることは疑いようのな い事実である. 2009 年 1 月 1 日現在で地上から観測可能な ものだけでも 12,743 個の人工物体か軌道上に存在し ${ }^{3)}$ ，地 上から追跡・検知が不可能な $1 \mathrm{~mm}$ 以上のものまで含める と推定では数千万個以上の物体が存在すると言われている． スペースデブリの発生源としては主に打上げによる人工物 体の増加, 衝突および爆発による破砕, また材料劣化によ る分離・離散がある.現在までに発生しているスペースデ ブリの多くは爆発や意図的破壞による破片であるが, 衝突 による破砕も北米国航空宇宙防衛司令部 (NORAD, North American Aerospace Defense Command)のカタログに 4 件記載されている4) . また，破片消滅に関しては，地球 の大気抵抗による落下, 人為的な回収や軌道離脱が考えら れるが，現状は大気抵抗による落下のみに頼っている状態 である．また，スペースデブリの消滅速度と生成速度が釣 り合ったときのデブリ空間密度を臨界密度と呼び, 衛星を 打ち上げただけで何も低減对策を施さなかった場合に自然 に物体数か増えていくか減っていくかを表す指標となる． Kessler ${ }^{5}$ や Eichler and Rex ${ }^{6)}$ の計算によると, 第 1 図に 示すように，高度 $1,000 \mathrm{~km}$ 付近と $1,500 \mathrm{~km}$ 付近では既に 臨界密度を超えている可能性があり，数值シミュレーション での検証が必要である.この現象は最初に指摘した米国航 空宇宙局 (NASA, National Aeronautics and Space Administration) の研究者の名前 (D. J. Kessler) にちなみ， ケスラーシンドローム (Kessler Syndrome) と呼ばれてい 


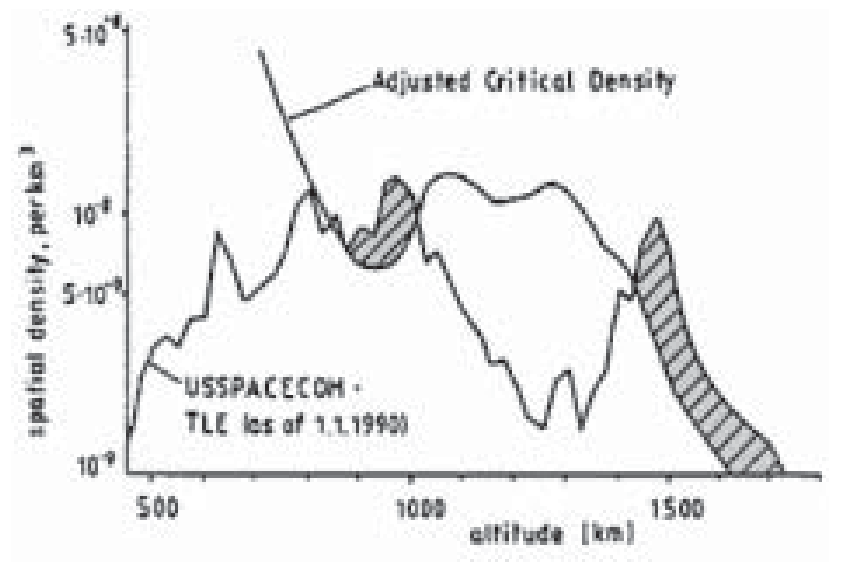

第1図 デブリの臨界密度 ${ }^{5}$ 斜線部分でケスラーシンドロームが 発生していると予測されている .

る. 現在のところ増加し続けているスペースデブリの低減 策として, 分離時などでの部品放出, 残留燃料の放出や電 池の破裂防止, 運用を終了した衛星を低軌道では大気抵抗 により 25 年内に自然落下する軌道, 静止軌道では高度が $300 \mathrm{~km}$ 以上離れた墓場軌道へ午れ光れ運用軌道から移行 させる PMD (Post-mission Disposal) が勧告されている . しかしながらこれらの対策だけではスペースデブリの増加 速度が遅くなるだけであり, 宇宙環境の保全には不十分で あると指摘されている7) . スペースデブリ発生およひ増加 を十分に防ぐために , デブリ除去衛星などを打ち上げて能 動的にデブリを取り除く ADR (Active Debris Removal) が必要であるとも指摘している. 実際, 宇宙航空研究開発 機構 (JAXA, Japan Aerospace eXploration Agency) で はマイクロリムーバや導電性テザーを用いたスペースデブ リ除去システムの検討が行われている8). ADR の有効性に ついて , NASA がスペースデブリ推移モデル LEGEND (a LEO-to-GEO Environment Debris model) を用いて シミュレーションを行っている．乥れによると，PMD など の従来議論されてきたデブリの低減方法ではデブリの増加 を $75 \%$ 程度にしか抑えることができないという．しかしな がら，PMDに加えて年間 5 個のペースで衝突破砕の危険 性の高いデブリを取り除くことで，低軌道の環境を現在の デブリ密度程度に保持できる7).この結果を受け, 国際機関 間スペースデブリ調整委員会 (IADC, Inter-Agency Space Debris Coordination Committee) では ADR の有効性を 各機関のスペースデブリ推移モデルを用いて確認すること となった .JAXA では九州大学と共同開発したスペースデ ブリ推移モデルで参加している.ADR の有効性についての シミュレートに先立ち, 今後, デブリの自己増殖が発生する という共通認識を持つため各機関の推移モデルでケスラー シンドロームの解析を行うことになった．ADR を効果的に 行う条件を議論する上でもケスラーシンドロームの詳しい 解析が必要である . そのためスペースデブリ推移モデルを 用いたシミュレートにより, 新規にロケットの打上げを行 わないシナリオで長期間にわたるデブリ密度の推移につい
ての解析を行うことが本研究の目的である . 今回 , IADC の出力要求である衝突と高度の観点からと独自に軌道傾斜 角の観点から軌道環境の安定性 (ケスラーシンドロームが 発生するかどうか) についての解析を行い, 弚の結果を基 にADRのより効率的, 効果的な条件について議論する.

\section{2. 低軌道地球環境推移モデル}

ケスラーシンドロームの解析には, JAXA が九州大学と共 同開発した低軌道環境推移モデル LEODEEM (Low Earth Orbital Debris Environment Evolutionary Model) を用 いる. LEODEEM とは, 近地点高度 $2,000 \mathrm{~km}$ 以下, サイ ズ $1 \mathrm{~cm}$ 以上の物体の軌道環境の推移を予測することが可 能なスペースデブリの環境予測モデルである . LEODEEM では太陽および月による引力, 大気抵抗，地球の非球体性， 太陽輻射圧による捸動を考慮して軌道計算を行い, 1 年ごと に衝突率を計算している.軌道上物体の爆発・衝突破砕が発 生した場合は，NASA 標準破砕モデル99) を用いて新規の破 片を発生させている．昨年度までは破片をパラメータで分 類していた .この方法は宇宙機やロケット上段機体といっ たインタクト (無傷) な物体は光れ光れ個別に計算をして， ミッション関連物体や破砕により発生した破片などの小さな 物体については, 近地点高度 $r_{\mathrm{p}}$, 遠地点高度 $r_{\mathrm{a}}$, 軌道傾斜 角 $i$ および弾道係数 BCの 4 つのパラメータで分類を行い， ほぼ同一の軌道上に存在する破片ごとでグループ分けを行 う方法である .これにより軌道計算は代表破片のみを取り 扱えばよく，計算時間が短縮できる．本年度 LEODEEM を改良し，予測する軌道物体の下限サイズを自由に設定で きるようにした．また，これまでは軌道上物体の種類によっ てパラメータで分類するか個別に計算するかを判断してい たが，今回，すべての軌道上物体に対して一律に $10 \mathrm{~cm}$ の サイズを基準に分類し，10 cm 以上の物体に対してはすべ て個別に軌道計算を行うようにした .これにより，10 cm 以 上の破片も個別に計算できるため，より正確な軌道環境の 推移を予測することが可能となる. 今回 , $10 \mathrm{~cm}$ 以上のデ ブリを対象に解析を行ったため，すべての軌道上物体に対 してグループ分けは行わず，個別に軌道計算を行った . 以 下に鳴海 ${ }^{10,11)}$ に基づいて , LEODEEM に用いられている 軌道計算, 衝突計算, 破砕モデルについて簡単に述べる.詳 細は鳴海を参照のこと．

2.1 軌道計算 軌道計算の方法については, 環境推移モ デルのような長期間の軌道要素の変化をみる場合, 物体の 短周期運動は軌道周期に近いため重要ではなく，長周期の 変化および永年変化である線形項のみが必要になる. 产こ でLEODEEM では軌道要素変化の時間平均をモデルに組 み込み，破片の軌道を計算している.地球の非球体性につ いては $J_{2}$ 項， $J_{3}$ 項， $J_{4}$ 項までを考慮し，重力ポテンシャ ルを軌道 1 周期分積分したものを Lagrange の惑星方程式 に代入することで, 軌道要素の時間平均された時間変化率 を取り出している.

$$
\bar{R}_{i}=\frac{1}{P} \int_{0}^{P} R_{i} \mathrm{~d} t=\frac{1}{2 \pi} \int_{0}^{2 \pi} R_{i} \mathrm{~d} M
$$


太陽と月の引力については距離による 2 次近似の厳密な積分 值を導出し，摂動関数を 1 周期分積分したものを Lagrange の惑星方程式に代入することで時間平均值を取り出してい る.太陽輻射圧および大気抵抗についても，Gauss の惑星 方程式を用いて軌道要素の変化率を導出している. 短周期 項も含めた数值解析による軌道計算では一般的に数秒から 数分といったオーダーのステップで計算を行うことが普通 であるが，LEODEEM で使用している短周期項などを取 り除いた解析的手法では最大 5 日程度のステップで計算が 可能である. 5 日超のステップになると月の引力による捸 動を正しく計算できなくなることから (月の公転周期が約 27.32 日であるため), 本研究でも計算ステップを 5 日とし ている. LEODEEM に用いられる軌道計算法の妥当性に ついては鳴海 ${ }^{10,11)}$ を参照のこと.

2.2 破砕モデル 爆発·衝突によって新たに発生した破片 の特性については, Bess ${ }^{12)}$ のモデル, McKnight ら ${ }^{13,14)}$ のモデル, $\mathrm{Su}^{15)}$ のモデル, Yasaka and Ishii ${ }^{16)}$ のモデ ル，NASA のモデルなど，樣々なものが存在しているが， LEODEEM では NASA 標準破砕モデルを用いて, 光の個 数, 質量, サイズ, 面積質量比, ならびに放出速度を計算 している.NASA 標準破砕モデルは過去の Solwind ガン マ線スペクトロメータ衛星を標的に用いた軌道上衝突実験， および実機に近い衛星を用いて地上で実施された SOCIT (Satellite Orbital debris Characterization Impact Test) を含む，これまでに実施された種々の超高速衝突実験を基 に構築されたモデルであり，面積質量比などの分布は正規 分布で表わされている. 衝突が完全破壊か部分破壊である かは, 2 物体のうち小さな物体が有する衝突時の運動エネ ルギーを大きな物体の質量で除算して得られる比によって 判断され，この比が $40 \mathrm{~J} / \mathrm{g}$ 以上であれば完全破壞であり， $40 \mathrm{~J} / \mathrm{g}$ より小さければ部分破壞であると定義されている .

$$
\begin{aligned}
& \frac{m_{2} U_{12}^{2}}{m_{1}} \geq 40[\mathrm{~J} / \mathrm{g}] \quad \text { Catastrophic } \\
& \frac{m_{2} U_{12}^{2}}{m_{1}}<40[\mathrm{~J} / \mathrm{g}] \quad \text { Non-catastrophic }
\end{aligned}
$$

2.3 衝突計算 2 物体間の衝突率を計算する方法を示す . まず物体間の最小距離か衝突限界距離 $d$ より小さくなつた 際に衝突の可能性が考えられると仮定する . また，すべて の組み合わせについて衝突率を計算するとなると膨大な計 算量となるため, 衝突率を計算していく際に 2 つのフィル タを用いて衝突し光うにない組み合わせを取り除いている. 第 1 のフィルタとして, 2 軌道の近地点と遠地点の值を比 ベている (第 2 図参照).

$$
r_{\mathrm{p} \max }-r_{\mathrm{a} \min }<d
$$

長半径の大きい方の軌道の近地点距離と長半径が小さい方 の軌道の遠地点距離との差が, 衝突限界距離よりも大きく なる場合は衝突する可能性はないと考える.このフィルタ は閉じた軌道ならば軌道平面が異なっていても使用するこ とが可能である .

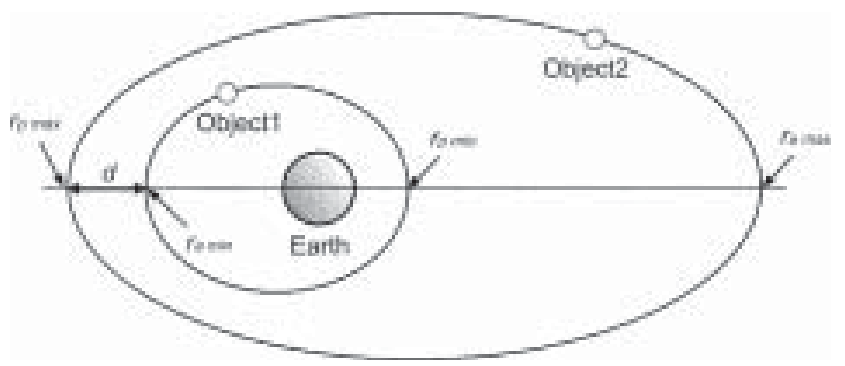

第2図遠近地点フィルタ

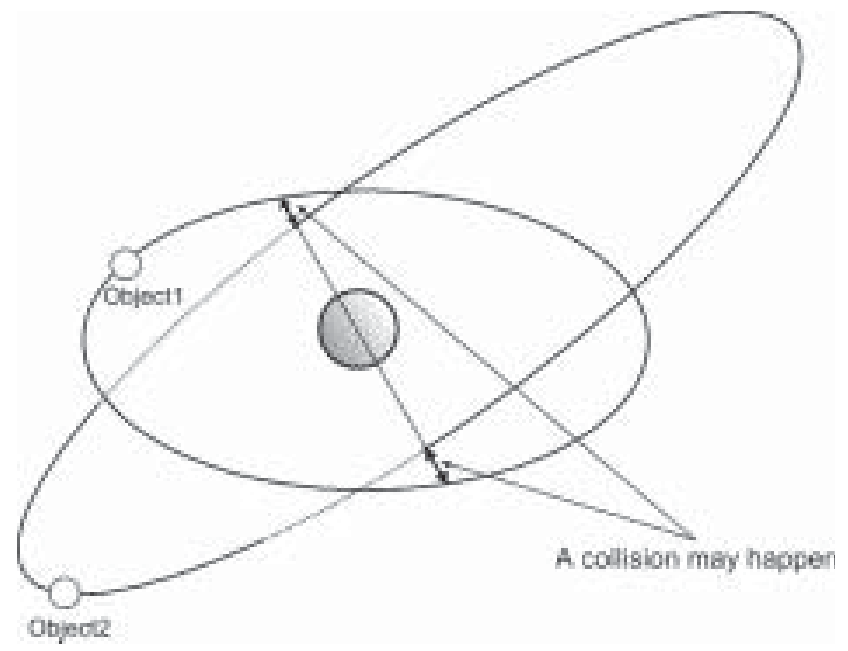

第3 図 軌道間最小距離フィルタ

第 2 のフィルタとして, 2 つの軌道間距離が最も小さく なる場所の距離を算出する .2 物体の距離が最小になる位 置は 2 つの軌道面が交差する直線状にあることがほとんど であり，光れに当てはまらないものに関しては無視できる ほど衝突率が低いため, 光のことを用いて軌道間最小距離 計算を行う (第 3 図参照). 従って, 軌道間距離が衝突限界 距離より大きな場合には衝突の可能性がないとする .

これらのフィルタを用いることにより，大幅な計算時間 の短縮が可能であることがわかっている．衝突率の計算は 上記の 2 つのフィルタを通過した，軌道間最小距離の近い 2 物体間で計算を行う. 計算には気体分子運動論を応用さ せた手法を，衝突球 (第 4 图参照) に適用した方法を用い る.ここで衝突球とは軌道上物体を中心に直径が衝突限界 距離の球のことを表している.軌道決定の誤差や捸動など から, 衝突球の内部で衝突が起こる可能性があると考える ある 1 個の物体が兴の他の物体と衝突する確率は, 断面積, 数密度および相対速度の積で与えられ, 物体は衝突球の重 なり合った部分で衝突することになり，物体が兴の部分に 存在する時間, 断面積, 相対速度を考慮することにより最 終的に衝突する確率が算出される．

$$
C_{12}=\frac{p_{2} \Delta V}{V} \frac{p_{1}}{V} A_{12} U_{12}
$$

最終的に算出された衝突率と乱数 ${ }^{17)}$ を比較することで衝 突が起きたかどうかを判定する . 


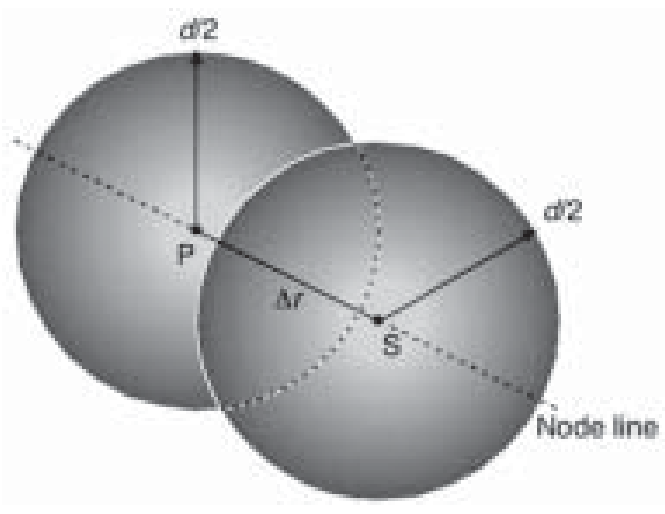

第 4 図 衝突球

$d:$ desired distance tolerance, $\Delta r$ : distance between objects.

\section{3. シミュレーション}

3.1 シミュレーション条件上で述べたような，軌道 計算, 破砕モデル, 衝突計算などをモデルとして組み込み， シミュレーションを開始する . 今回 , ケスラーシンドロー 厶の解析には新規にロケットの打上げを行わないシナリオ で行う.さらに，軌道上での爆発破砕は完全に抑制されて いると仮定する．これは, 実際には軌道上での爆発破砕や 新規ロケットの打上げが行われているが , デブリの増加原 因を衝突破砕のみに限定することで, 現状の地球軌道環境 が安定であるのか不安定であるのかを議論するためである . また , シミュレーション期間は 2006 年 1 月 1 日から 200 年間とし，60 回のモンテカルロシミュレーションを行う. モンテカルロシミュレーションにおける計算回数について は, 異なる乱数のシードを用いたモンテカルロシミュレー ションを 30 回程度行えば十分であることは Liou'18) などに よって明らかにされているので, 十分な計算回数である . シ ミュレーションの初期条件として, IADC がこの研究のた めに用意したデータを使用する .このデータは実際の観測 データを基に ESA (European Space Agency) の環境モデ ルMASTER 2005 で作成された，2006 年 1 月 1 日時点で の $10 \mathrm{~cm}$ 以上の近地点高度 $2,000 \mathrm{~km}$ 以下のスペースデブ リのデータである .このデータは軌道上物体の種類, 質量 , 断面積, 軌道要素をまとめたデータであり, 本研究ではこ のデータを初期条件として読み込み, $10 \mathrm{~cm}$ 以上の軌道上 物体について解析を行う. 第 5 図は今回のシミュレーショ ンの流れを表している.

3.2 計算結果 第 6 図は 2006 年, 2106 年, 2206 年㶢 れぞれにおけるデブリ密度分布を表したグラフである . デ ブリの密度作成にあたって，光れ光れの軌道上物体は離心 率を持っているためただ単純に近地点距離のみではデブリ の高度を決めることができない，弚のためデブリが地球を 1 周する間に光れ光れの高度に滞在する時間を基に密度分 布を作成した . ケスラーシンドロームが発生すると予測さ れている高度 $900 〜 1,000 \mathrm{~km}$ と 1,400〜 1,500 km を比較す ると両方の高度で今後 200 年間の間にデブリが自己増殖

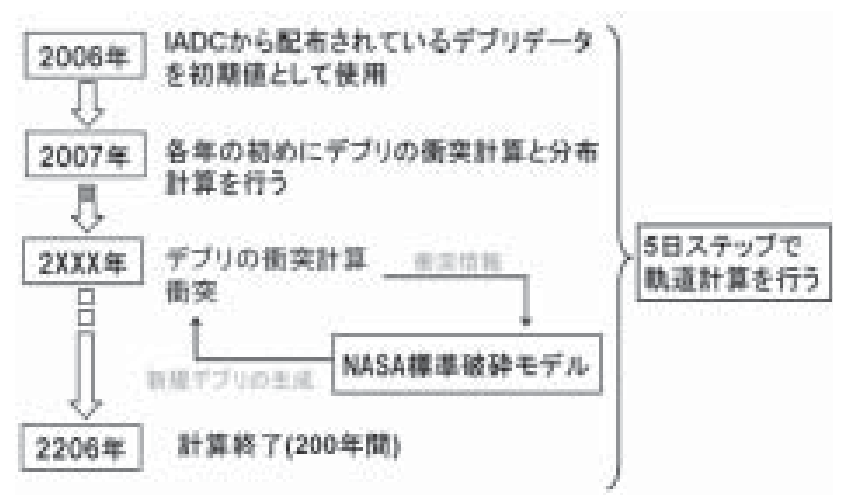

第5図 シミュレーションの流れ

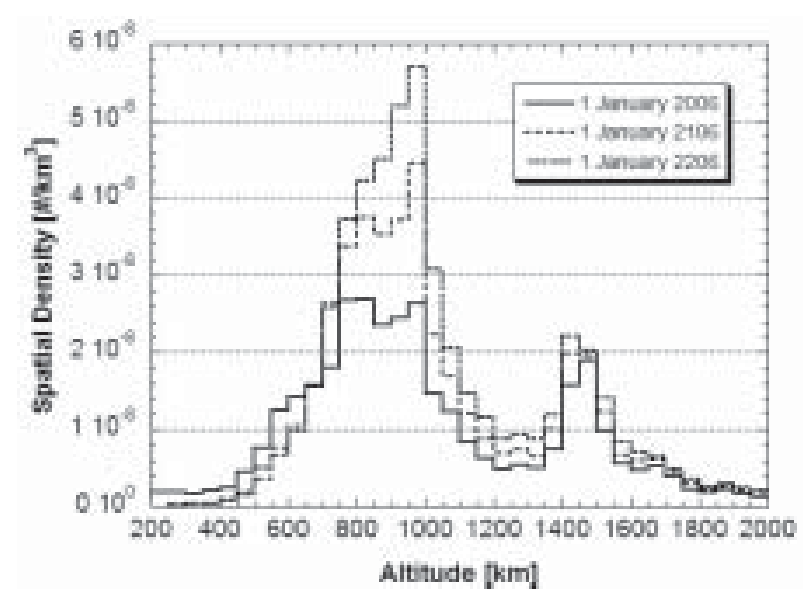

第 6 図 デブリ密度分布 $(10 \mathrm{~cm}$ 以上 $)$

している . 加えて , 900〜 1,000 km の高度でよりデブリの 増加が著しいことが読み取れる．この結果から高度 900〜 $1,000 \mathrm{~km}$ における軌道上物体の種類別の推移について解析 を行うと第 7 図のようになる.シミュレーション条件として 新規打上げ, 爆発破砕がないと仮定しているため, 初期状 態で支配的であった無傷の物体数と爆発破砕由来の破片は シミュレーション期間の経過とともに減少しているが, 乥れ 以上に衝突破砕由来の破片が増加しているため，デブリの 数か増加している. 关れにより今後, 高度 $900 \sim 1,000 \mathrm{~km}$ の軌道環境は衝突破砕由来の破片が支配的になると予測で きる .

第 8,9 図は 200 年間のモンテカルロシミュレーションを 通じての衝突破砕の累積数を表している .このグラフから 完全破壊による衝突破砕, 部分的破壊による衝突破砕, 合 わせて 35 回以上が今後 200 年間で発生することがわかる . また，グラフ上の点線は衝突破砕が 1 回発生する年を基準 とした基準線である .この基準線から完全破壊による衝突， 部分破壊による衝突両方の衝突破砕とも増加傾向にあるこ とか読み取れる．さらにグラフから完全破壊による衝突の 回数の増加に比べて部分破壊による衝突の回数の増加のほ うが大きいことも読み取れる．これは衝突を繰り返すこと でサイズの小さい破片の割合が大きくなっているためだと 考えられる．弚のため小さい破片では衝突の規模が小さく 


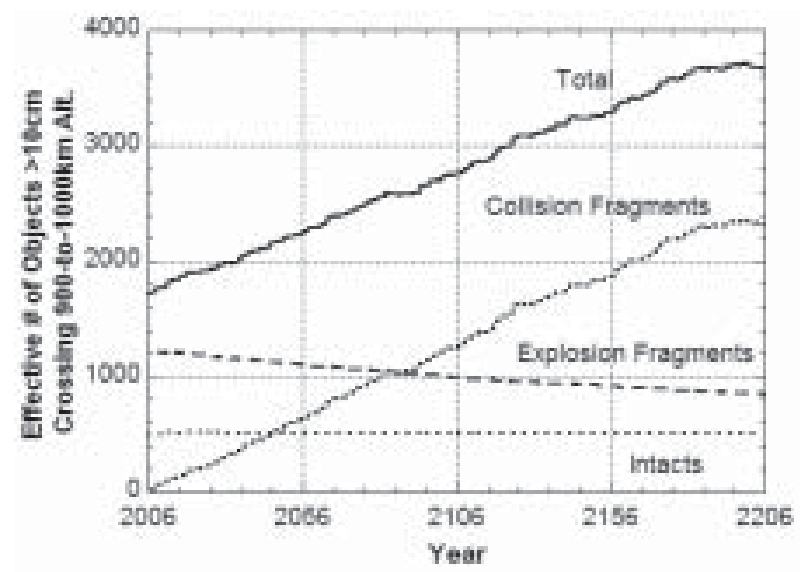

第 7 図 高度 900 〜 $1,000 \mathrm{~km}$ におけるデブリ数の推移

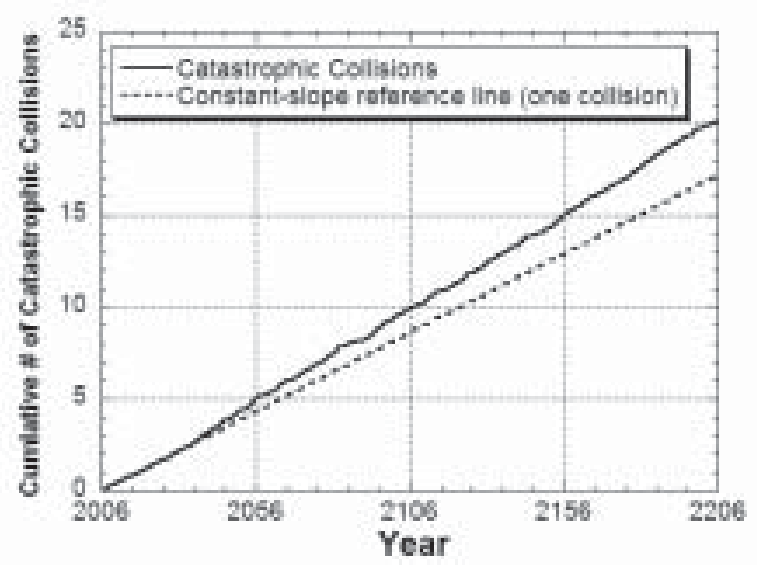

第 8 図 完全破壊による衝突破砕の累積回数と基準線との比較

なるため部分破壞衝突の割合が増加すると考えられる .こ のことは第 6 图におけるデブリ密度分布からも考えること ができる .なぜならば, 衝突破砕の回数は増加傾向にある のに対して , デブリ総数の増加量は徐々に減少している.つ まり衝突破砕 1 回で $10 \mathrm{~cm}$ 以上のデブリ発生量が減少して いることを示している．以上のことから，軌道上物体のサ イズが小さくなることで, 衝突の規模が小さくなっている と考えられる .

第 10 図はシミュレーション期間全体における衝突の高度 分布を表している . 衝突の高度分布と第 6 图のデブリ密度 分布を比較するとシミュレーションにおいて, 衝突破砕の ほとんど起こっていない高度 $1,100 〜 1,300 \mathrm{~km}$ においても デブリの数か増加している .この増加の原因としてデブリ が衝突した際，樣々な離心率を持ったデブリが生じるため だと考えられる .つまり高度 900〜 1,000 km での衝突によ り周辺の軌道環境にも影響を与えて, 悪化させるというこ とである.したがって，900〜1,000 km の衝突を防止する ことでその軌道の環境だけでなく，周辺軌道の環境悪化の 防止になると予測できる . また高度 $800 \mathrm{~km}$ 付近の太陽同 期軌道でも複数回の衝突が発生しており, 軌道環境の悪化 に影響を与えていると考えられる．

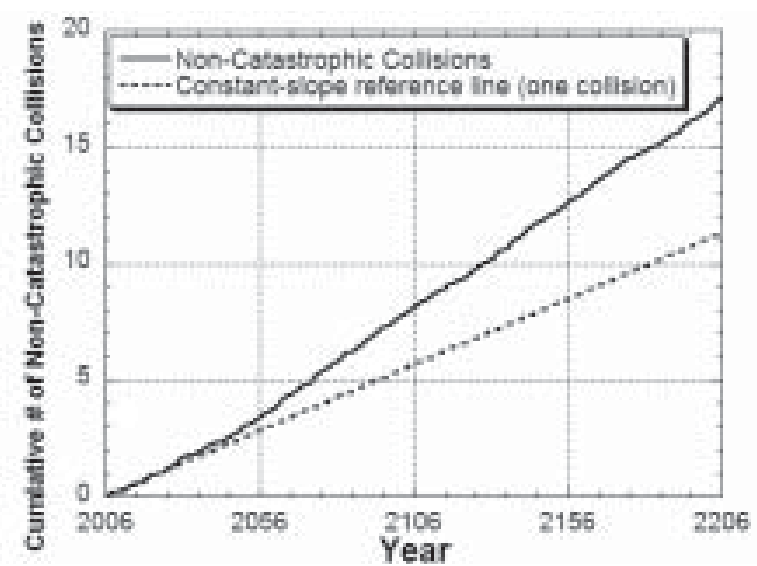

第 9 図 部分破壞による衝突破砕の累積回数と基準線との比較

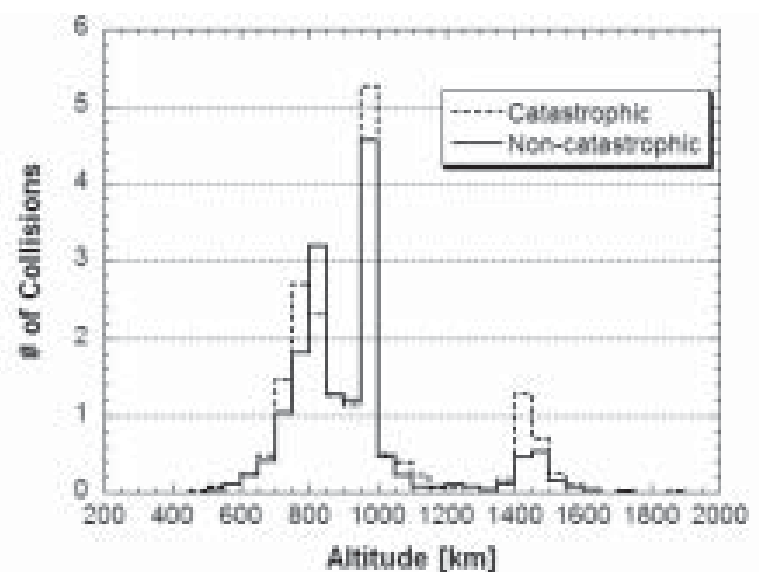

第 10 図完全破壞，部分破壊による衝突破砕の高度分布

次に, 軌道傾斜角の観点からケスラーシンドロームの解 析を行う.第 11 図は高度 $200 〜 2,000 \mathrm{~km}$ におけるデブリ の傾斜角分布を表している.このグラフより初期值におい てデブリの数が最も多い軌道傾斜角 83 度付近で大幅なデ ブリ増加が発生していることが読み取れる．加えて，軌道 傾斜角 72 度付近でも増加がみられるが, 弚の増加量は軌 道傾斜角 83 度と比較すると限定的である. この結果から デブリの密度分布を軌道傾斜角 $82 \sim 84$ 度と光れ以外に分 けて解析を行った (第 12,13 図参照) .このグラフから高 度 900〜1,000 km のデブリを増加させる最大の要因か軌道 傾斜角 83 度にあることか読み取れる.また , 光の他の傾斜 角では高度 $750 \mathrm{~km}$ 以下の低軌道を除いてどの高度でもほ ぼ一定数のデブリを増加させている .さらに光の増加量も 限定的である . 以上のことから高度 $900 \sim 1,000 \mathrm{~km}$ て軌道 傾斜角 83 度のデブリが最もデブリの自己増殖に関与する ことが明らかとなった . これは特定の高度と軌道傾斜角上 に一定密度を超えるデブリが存在すると大幅な自己増殖が 発生することを意味する .すなわちデブリの増加防止のた めにはこの条件のデブリを集中して除去することが効果的 であると考える 


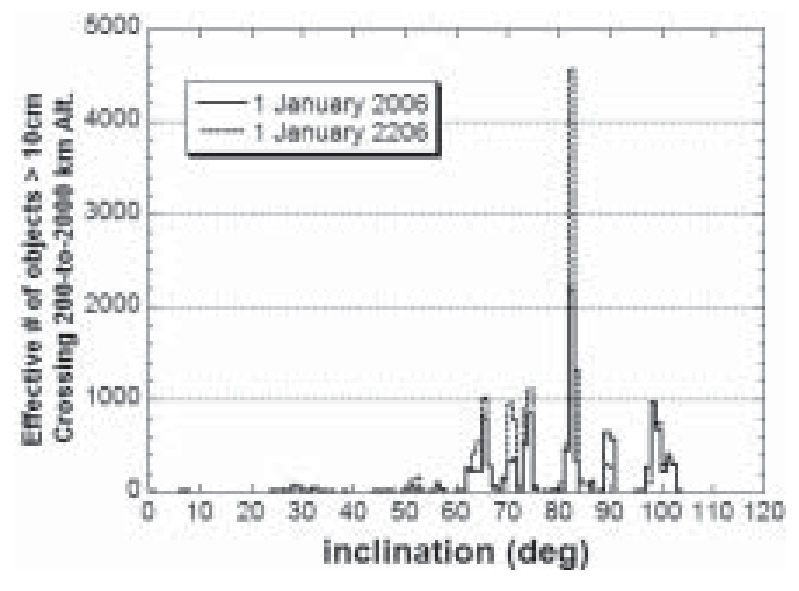

第 11 図 デブリの軌道傾斜角分布

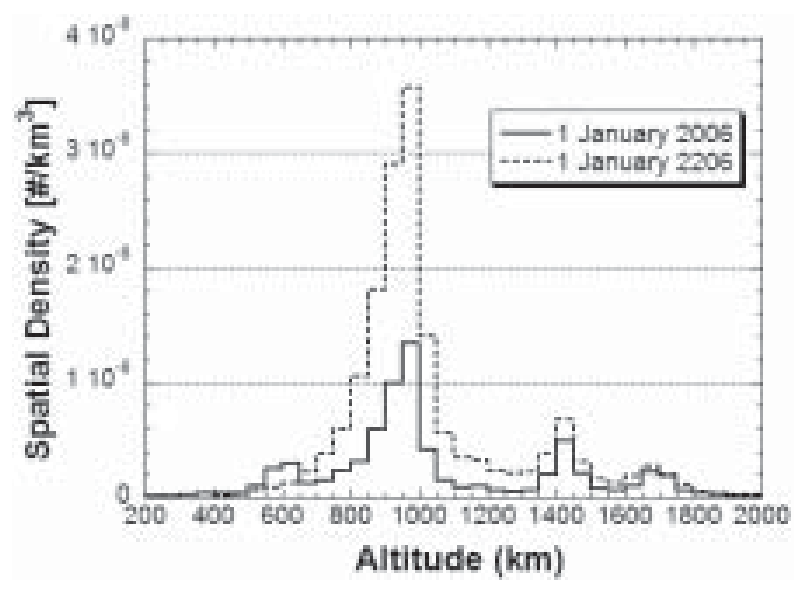

第 12 図 軌道傾斜角 82 ～ 84 度におけるデブリ密度分布

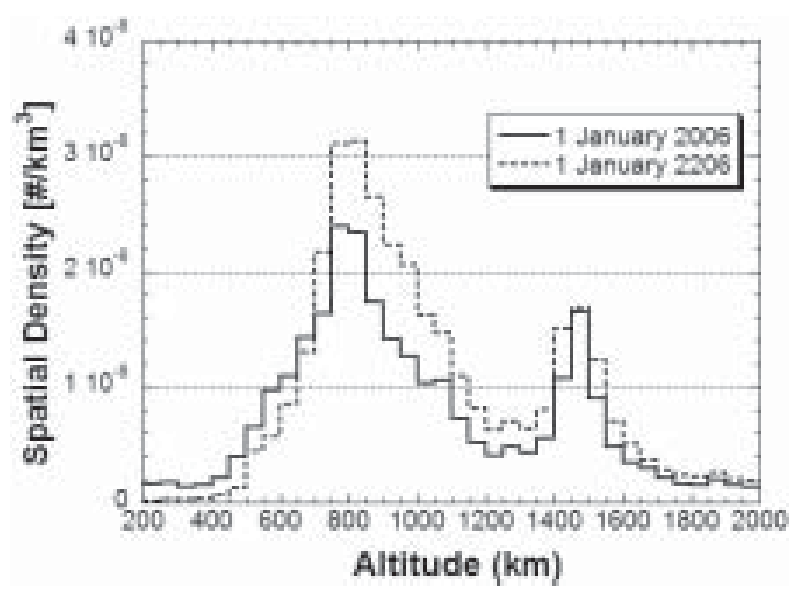

第13 図 軌道傾斜角 82〜84 度以外のデブリ密度分布

4. 結言

今回 , サイズ $10 \mathrm{~cm}$ 以上の軌道上物体に対して新規にロ ケットの打上げ, 軌道上での爆発破砕がない条件で低軌道環 境推移モデル LEODEEM を用いたケスラーシンドローム の解析を行った . 解析の結果から以下の結論が導き出せる.

1) 完全破壞の衝突破砕, 部分破壊の衝突破砕ともに今
後 200 年間で主に高度 $700 \mathrm{~km}$ から $1,000 \mathrm{~km}$ の間で発生 し, 衝突破砕由来の破片がデブリの半数を占めるようにな る . ケスラーシンドロームが発生すると予測されている高 度 $1,400 \mathrm{~km}$ から $1,500 \mathrm{~km}$ においてもデブリの増殖がみら れたが限定的である .

2) デブリの衝突破砕の発生頻度は今後増加傾向にある .

3) 衝突破砕で生じたデブリは衝突した高度だけでなく， 樣々な離心率を持つことで周辺の高度の軌道環境をも悪化 させる .

4) デブリは高度 $900 \mathrm{~km}$ から $1,000 \mathrm{~km}$ の間で軌道傾斜 角 83 度付近で大幅に増加する. 軌道傾斜角 83 度付近以外 の軌道傾斜角のデブリ増加は軌道傾斜角 83 度付近と比較 して限定的である.このことは特定の高度と軌道傾斜角上 に一定密度を超えるデブリが存在すると大幅な自己増殖が 発生することを意味する .

今回 , デブリの自己増殖はみられたがケスラーの予測に みられるような指数関数的な増加はみられず, むしろわず かながら増加の割合が減少していた . 原因として, 本研究 は $10 \mathrm{~cm}$ 以上のデブリしか存在しないと仮定をしているた めだと考えられる . デブリの発生ルーチンでも $10 \mathrm{~cm}$ 末満 のデブリは取り除いている. 并のため軌道上物体に色険を 及ぼす可能性のある $10 \mathrm{~cm}$ 以下のデブリまで考慮していな い. NASA 標準破砕モデルでは衝突破砕の際にサイズの小 さいデブリほど多く発生するため, より小さいサイズまで 考慮すればより多くの衝突破砕が発生し, デブリが多く発 生するのは明らかである . 加えて , 今回は衝突破砕のみを 考慮したが現実には新規打上げや軌道上での爆発破砕も行 われている.したがって，この結果のみで指数関数的な増加 は発生しないと結論付けることはできない．しかしながら， 現状の軌道環境で $10 \mathrm{~cm}$ 末満のデブリを取り除いた条件に おいても, デブリの自己増殖が発生するのは解析したデー タから明らかである．弚のため今回のシミュレーションで 最も顕著にデブリの衝突, 増加がみられる, 高度 $900 \mathrm{~km}$ か ら $1,000 \mathrm{~km}$ の間で軌道傾斜角 83 度等のデブリや太陽同期 軌道に存在するデブリを能動的に除去する必要がある．今 後この条件でデブリを除去した場合の低軌道宇宙環境への 影響についてシミュレートを行い, JAXA が検討している デブリ除去衛星の効果についても議論を進めたい .

\section{参 考 文 献}

1) United Nations Adopts Space Debris Mitigation Guidelines, Orbital Debris Quarterly News, 11, 4 (2007), pp. 3-4.

2) United Nations Adopts Space Debris Mitigation Guidelines, Orbital Debris Quarterly News, 12, 3 (2008), pp. 3-6.

3) Fengyun-1C Debris: Two Years Later, Orbital Debris Quarterly News, 13, 1 (2009), p. 2.

4) Accidental Collisions of Cataloged Satellites Identified, Orbital Debris Quarterly News, 9, 2 (2005), p. 1.

5) Kessler, D. J.: Collisional Cascading: The Limits of Population Growth in Low Earth Orbit, Adv. Space Res., 11, 12 (1991), pp. 63-66.

6) Eichler, P. and Rex, D.: Chain Reaction of Debris Generation by Collisions in Space - a Final Threat to Spaceflight? Acta Astronautica, 22 (1990), pp. 381-387.

7) Liou, J.-C. and Johnson, N. L.: An Assessment of the Cur- 
rent LEO Debris Environment and What Needs to Be Done to Preserve It for Future Generations, ISTS 2008-r-2-29 presented at the 26th International Symposium on Space Technology and Science, Hamamatsu, Japan, 2008.

8) Kawamoto, S.: Strategy for Active Debris Removal Using Electrodynamic Tether, ISTS 2008-r-2-26 presented at the 26th International Symposium on Space Technology and Science, Hamamatsu, Japan, 2008.

9) Johnson, N. L., Krisko, P. H., Liou, J.-C. and Anz-Meador, P. D.: NASA's New Breakup Model of EVOLVE 4.0, Adv. Space Res., 28 (2001), pp. 1377-1384.

10) 鳴海智博 : 地球低軌道におけるスペースデブリの環境推移モデル， 平成 19 年度九州大学博士論文, 2008 。

11）鳴海智博, 花田俊也, 河本聡美 : 地球低軌道スペースデブリ環境 における推移モデル，宇宙技術， 7 (2008), pp. 11-17.

12) Bess, T. D.: Mass Distribution of Orbiting Man-Made Space Debris, NASA TN D-8108, 1975.

13) McKnight, D. S., Johnson, N. L., Fudge, M. L. and Maclay, T. D.: Satellite Orbital Debris Characterization Impact Test
(SOCIT) Series Data Collection Report, Kaman Sciences Corp., Contract NAS 9-19215, Alexandria, VA, 1995.

14) McKnight, D. S., Johnson, N. L., Fudge, M. L. and Maclay, T. D.: Analysis of SOCIT Debris Data and Correlation to NASA's Breakup Models, Kaman Sciences Corp., Contract NAS 9-19215, Alexandria, VA, 1995.

15) Su, S.-Y.: The Velocity Distribution of the Collisional Fragments and Its Effect on the Future Space Debris Environment, Adv. Space Res., 10 (1990), pp. 389-392.

16) Yasaka, T. and Ishii, N.: Breakup in Geostationary Orbit: A Possible Creation of a Debris Ring, Proceedings of the IAA held in Conjunction with the 42nd IAC, Montreal, Canada, 1991, pp. 203-216.

17) Press, W. H., Teukolsky, S. A., Vetterling, W. T. and Flannery, B. P.: Numerical Recipes in C++: The Art of Scientific Computing, Second ed., Cambridge University Press, New York, 2005.

18) Liou, J.-C.: A Statistical Analysis of the Future Debris Environment, Acta Astronautica, 62 (2008), pp. 264-271. 